\title{
Assessment of Clinical Indications for Caesarean Section in Mosul City Hospitals: A Cross-Sectional Study
}

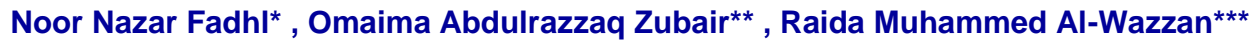 \\ *Postgraduate Student, Department of Family and Community Medicine, College of Medicine University \\ of Mosul , ${ }^{*}$ Department of Family and Community Medicine, College of Medicine , University of Mosul , \\ ${ }^{* * *}$ Department of Obstetrics and Gynecology , College of Medicine , University of Mosul , Mosul, Iraq \\ Correspondence: noor.nazar.fadel@gmail.com
}

(Ann Coll Med Mosul 2021; 43 (1):48-54).

Received: $28^{\text {th }}$ Nove. 2020; Accepted: $12^{\text {th }}$ Janu. 2021.

\begin{abstract}
Background: Caesarean section is traditionally done when a vaginal delivery would put the mother or fetus's life at risk. Knowing the indications of the caesarean section will help to have an impression of this common type of the obstetric procedures. The aim of the current study was to examine the indications of caesarean sections which are undertaken in Mosul city hospitals.

Methods: A cross-sectional study was done at eight hospitals in Mosul city and a sample of 671 women who were delivered by caesarean section was included in this study. The necessary agreement was obtained from all the participants in the sample.

Study period: the study was done during the period from $15^{\text {th }}$ November 2019 to $15^{\text {th }}$ April 2020. The information was taken by direct interview with the women who were delivered by caesarean section and from their hospital case sheets.

Results: Primary caesarean section was reported in $45.2 \%$ of cases followed by previous two or more CS in $32.3 \%$ and those with previous one caesarean section with other causes $22.5 \%$ with a very highly statistically significant difference $(P=0.001)$. Fetal distress was the indication for primary caesarean section in one-quarter of cases $25.4 \%$ with a very highly statistically significant_difference $(P=0.000)$ from other causes. Maternal request constituted $11.5 \%$ of indications among the participant women and it constituted onequarter of causes among women with previous one caesarean section $(P=0.000)$.

Conclusions and recommendations: Primary caesarean section constituted the highest number among caesarean section indications in the current study, followed by previous two or more caesarean section and then previous caesarean section with other causes. Fetal distress was the highest indication in primary caesarean section cases. The study recommends to improve health education to the mother about the risk of caesarean section and possibility of normal delivery after primary caesarean section.
\end{abstract}

Keywords: Caesarean section, primary caesarean section, indications for caesarean, maternal request, Mosul city.

$$
\begin{aligned}
& \text { تقيم الدواعي السريرية للولادة القيصرية في مستشفيات مدينة }
\end{aligned}
$$

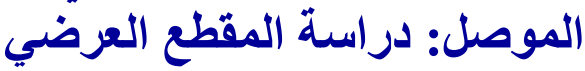

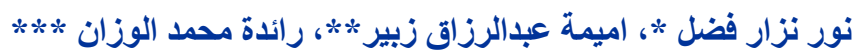

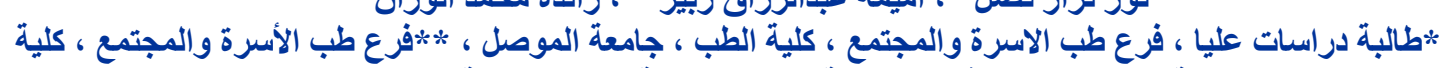

$$
\begin{aligned}
& \text { الطب ، جامعة الموصل ، ***:فرع النسائية والتوليد ، كلية الطب ، جامعة المعل الموصل ، الموصل ، العراق }
\end{aligned}
$$

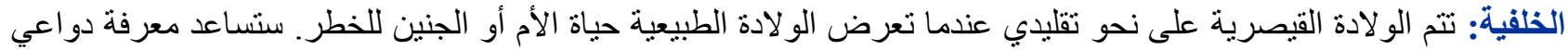

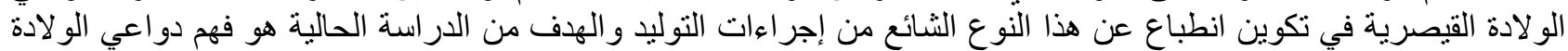

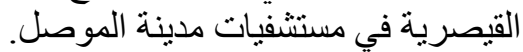

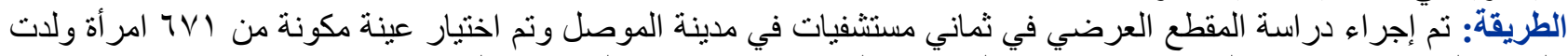
بالو لادة القيصرية في إجراء دراء الدراسة كما واخذت المو افقات الضروريةً من جميع النسوة في العينة. 


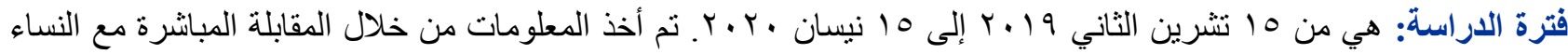

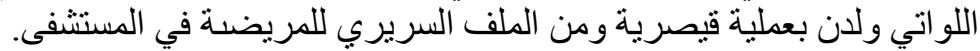

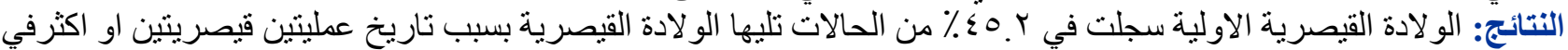

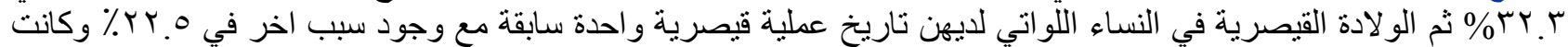

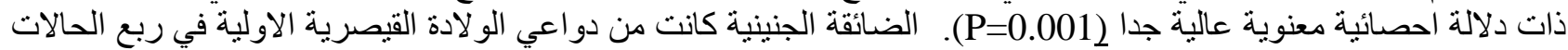

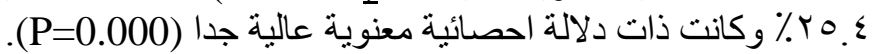

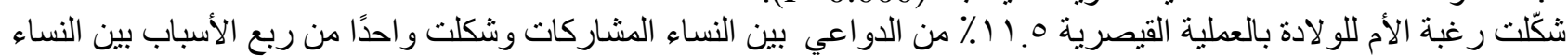
اللواتي خضعن لعملية قيصرية سابقة (P=0.000).

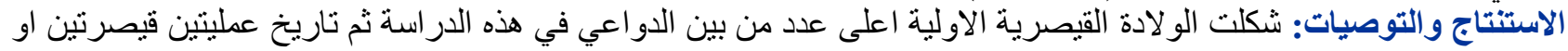

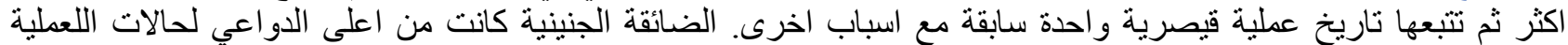

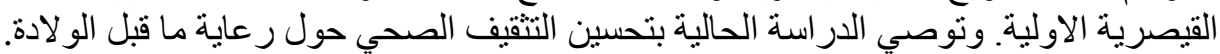

الكلمات المفتاحية: الو لادة القيصرية، الولادة القيصرية الأولية، دو اعي الو لادة القيصرية، رغبة الأم، مدينة الموصل.

\section{INTRODUCTION}

C aesarean section (CS) is the delivery of a fetus through surgical incision which done through the abdominal wall (laparotomy) and the uterine wall (hysterotomy) and it is known as caesarean delivery or C-section ${ }^{1}$. It was initiated as a lifesaving procedure in clinical practice for both the fetus and the mother and it was considered as one of the most emergency obstetrical operation done when unexpected complications were occurred during labor and it can be scheduled and done electively. Although CS was relatively safe but still it is a major surgery and recovery was relatively longer and more complications than that of the vaginal birth ${ }^{2}$.

World Health Organization (WHO) stated that CS should be implemented when only there was a medical causes but some of CS were implemented without any medical cause only upon maternal request $^{3}$.

There are many different indications for CS and the four major indications which accounting for more than $70 \%$ of all operations are previous multiple CS; abnormal presentation (commonly breech presentation); failure to progress of labor; suspected fetal distress and other indications such as placenta praevia, abruptio placentae, multiple pregnancy, maternal disease and fetal disease ${ }^{4}$. Indications for CS can be divided into absolute and relative indications ${ }^{5}$. Absolute indications when the vaginal delivery was not possible and there was a life threatening condition to the pregnant women and it was about $1-2 \%$ of all deliveries. These absolute indications are severe and uncontrolled antepartum hemorrhage, persistent of abnormal presentation, rupture of the uterus ${ }^{6}$, previous two or more CS ${ }^{7}$, absolute cephalo-pelvic disproportion ${ }^{8}$ and atypical cases of CS after the mother death (post mortem birth) ${ }^{9}$. The relative indications for CS in which the decision to do CS consider the benefit to risk for the mother and the fetus ${ }^{10}$ and it include many indications. Previous CS if there are no other indications for CS with it considered as relative indication, as trial of labor after caesarean could be attempted ${ }^{11}$ with good success rate ${ }^{12}$. The other relative indications for CS are dystocia, abnormal presentation, bad obstetrical history, multiple pregnancy, relative cephalo-pelvic disproportion and others. Caesarean section on maternal request defined as $\mathrm{CS}$ in the absence of fetal and maternal indications for CS and it is one of the causes for increase in CS rate ${ }^{13}$. Normally people are afraid from any surgery except CS and many of them insist on CS from the beginning of their pregnancy as well as they came to hospital very happy like when go to a wedding and they really put pressure on her obstetrician to deliver by $\mathrm{CS}^{14}$. The mother who preferred CS reflects the usual idea in society that elective CS is safer than vaginal delivery for both mother and fetus, due to fear from vaginal delivery, to avoid delivery pain, to obtain tubal ligation or due to social reasons including choosing good timing ${ }^{13,15}$.

\section{PATIENTS AND METHODS}

Before starting to collect information firstly approval was taken from the College of Medicine University of Mosul and directed to the Nineveh Health Directorate and then the Training Center and Human Development was approved for the research project. A task facilitation was mentioned that includes the name of the hospitals covered in the study after which the letter of the task was handed over to the hospital director or his representative in order to facilitate the task of collecting information from patients and also taking statistical information from that hospital. 
The current study is a descriptive cross-sectional study which was done at all maternity hospitals in Mosul city, from the right side four hospitals included, three governmental hospitals (Al-Batool, Nablus and Mosul General Hospital) and one private hospital (Nineveh Private Hospital) and from the left side also four hospitals included two governmental hospitals (AI-Khansa and Al-Salam Teaching Hospital) and two private hospitals (AlZahrawi and Al-Rabee Private Hospitals). The period of data collection started from the $15^{\text {th }}$ November 2019 to 15 April 2020.

Sample size are 671 women who delivered by CS. Method of taking the sample was random continiuous sampling. The inclusion criteria were woman delivered by CS in Mosul city hospitals and the exclusion criteria were woman delivered by vaginal delivery, instrumental deliveries and any woman refused to participate in the current study.

The information was collected from women after clarifying the idea (aim and method) of the study. A verbal agreement with written consent were taken from all the participants in the sample. The information were analyzed using SPSS version 23, Chi-square test (Goodness of Fit) was used for strata justification, equal proportions was used when performing chi-square test, $P$ value of $(<$ 0.05 ) was considered as statistically significant.

\section{RESULTS}

Six hundred seventy-one women who underwent CS in Mosul city hospital were included in the study. About three quarters $(70.6 \%)$ of the study sample were in the age group 20-35 years, the mean $\pm S D$ of age was $28.89 \pm 6.61$ years. The women who were living in urban area constituted $59.5 \%$ of the sample. The highest number had primary school education $48.4 \%(\mathrm{P}=$ $0.000)$. Three-quarters of women $(75.3 \%)$ were multiparous with significant difference $(P=0.000)$ as it is shown in table 1.
Table 1: Some demographic and obstetrical characteristics of the study population

\begin{tabular}{|c|c|c|c|}
\hline Parameters $(n=671)$ & No. & $\%$ & P-value ${ }^{*}$ \\
\hline \multicolumn{4}{|l|}{ Age (years) } \\
\hline$<20$ & 49 & 7.3 & \multirow{3}{*}{0.000} \\
\hline $20-35$ & 474 & 70.6 & \\
\hline$\geq 35$ & 148 & 22.1 & \\
\hline Mean age \pm SD & \multicolumn{2}{|c|}{$28.89 \pm 6.61$} & \\
\hline \multicolumn{4}{|l|}{ Place of residence } \\
\hline Urban & 399 & 59.5 & \multirow{2}{*}{0.000} \\
\hline Rural & 272 & 40.5 & \\
\hline \multicolumn{4}{|l|}{ Maternal education } \\
\hline Illiterate & 177 & 26.4 & \multirow{5}{*}{0.000} \\
\hline Primary school & 325 & 48.4 & \\
\hline Secondary school & 98 & 14.6 & \\
\hline University & 67 & 10.0 & \\
\hline Higher education & 4 & 0.6 & \\
\hline \multicolumn{4}{|l|}{ Parity } \\
\hline 0 & 166 & 24.7 & \multirow{3}{*}{0.000} \\
\hline $1-5$ & 438 & 65.3 & \\
\hline$\geq 6$ & 67 & 10.0 & \\
\hline Total & 671 & 100 & \\
\hline
\end{tabular}

* Chi-square test (Goodness of Fit) was used.

Among study participants women, elective CS constituted more than half of the cases $57.5 \%$ when compared with emergency CS $42.5 \%$ with significant statistical difference $(P=0.000)$ and there were two groups of women according to the history of previous CS. First group for women with unscarred uterus (no history of CS) which constituted $45.2 \%$ and the second group for women with scared uterus (previous history of CS) which constituted $54.8 \%(P=0.012)$. The highest number of previous history of CS was 6 . History of previous one CS constituted $41 \%$ of cases in the second group with significant statistical difference $(P=0.000)$ as showed in table 2 . 
Table 2: Distribution of the study population according to the types of CS and history of previous caesarean section

\begin{tabular}{|c|c|c|c|}
\hline Type of CS & $\begin{array}{l}\text { No. }(n=67 \\
\text { 1) }\end{array}$ & $\%$ & $\begin{array}{l}\mathbf{P} \text { - } \\
\text { value }\end{array}$ \\
\hline Elective & 386 & 57.5 & \multirow{2}{*}{0.000} \\
\hline Emergency & 285 & 42.5 & \\
\hline \multicolumn{4}{|c|}{ History of previous CS } \\
\hline $\begin{array}{l}\text { No history of CS } \\
\text { (unscarred } \\
\text { uterus) }\end{array}$ & 303 & 45.2 & \multirow{2}{*}{0.012} \\
\hline $\begin{array}{l}\text { History of CS } \\
\text { (scared uterus) } \\
(n=368)\end{array}$ & 368 & 54.8 & \\
\hline 1 & 151 & 41.0 & \multirow{6}{*}{0.000} \\
\hline 2 & 98 & 26.6 & \\
\hline 3 & 68 & 18.5 & \\
\hline 4 & 34 & 9.2 & \\
\hline 5 & 12 & 3.3 & \\
\hline 6 & 5 & 1.4 & \\
\hline
\end{tabular}

Among 671 participated women, $22.5 \%$ of them had history of previous one CS with other cause while $32.3 \%$ of the participants had history of previous two or more CS. The remaining $45.2 \%$ from the study population were primary CS. In table 3 shows that the most common causes of primary CS was fetal distress as it constituted one quarter of the all causes $(25.4 \%)$ with a significant statistical difference $(P=0.000)$, multiple causes for indication for CS was $19.8 \%$. while abnormal presentation cause constitute $18.2 \%$ from all causes. Failure to progress of labor formed $13.2 \%$, maternal request (without any other obstetrical indication) was reported in $12.2 \%$, antepartum hemorrhage $8.6 \%$. Obstructed labor (midwife interference) represent $1.9 \%$ of the causes and fetal abnormality (hydrocephalus) was the lowest cause of primary CS indications $0.7 \%$.
Table 3:Indications of Primary caesarean section among study population

\begin{tabular}{|c|c|c|c|}
\hline $\begin{array}{l}\text { Indications of Primary CS } \\
\qquad(n=303)\end{array}$ & No. & $\%$ & $\begin{array}{c}\text { P- } \\
\text { value* }\end{array}$ \\
\hline Fetal distress & 77 & 25.4 & \multirow{8}{*}{0.000} \\
\hline $\begin{array}{l}\text { More than one cause for } \\
\text { CS(other than previous CS) }\end{array}$ & 60 & 19.8 & \\
\hline Abnormal presentation & 55 & 18.2 & \\
\hline Failure to progress of labor & 40 & 13.2 & \\
\hline Maternal request & 37 & 12.2 & \\
\hline Antepartum hemorrhage & 26 & 8.6 & \\
\hline $\begin{array}{l}\text { Obstructed labor (midwife } \\
\text { interference) }\end{array}$ & 6 & 1.9 & \\
\hline $\begin{array}{l}\text { Fetal abnormality } \\
\text { (hydrocephalus) }\end{array}$ & 2 & 0.7 & \\
\hline Total & 303 & 100.0 & \\
\hline
\end{tabular}

Evaluation of causes of CS in women with previous one CS showed that quarter of cases $26.5 \%$ was due to maternal request which had significant statistical difference $(P=0.000)$ from other causes. Failure to progress of labor and fetal distress constituted the second and third causes and it reported in $19.9 \%$ and $17.9 \%$ respectively among them and then followed by abnormal presentation $13.9 \%$, hypertensive disorder of pregnancy $8.6 \%$, postdate $6.6 \%$, antepartum hemorrhage $4.0 \%$, multiple pregnancy $1.9 \%$ and fetal abnormality (hydrocephalus) $0.7 \%$ as appeared in table 4.

Table 4: Distribution of the study population according to the history of other cause with previous one CS

\begin{tabular}{|c|c|c|c|}
\hline $\begin{array}{l}\text { Other cause with } \\
\text { previous one CS }\end{array}$ & No. & $\%$ & $\begin{array}{c}\mathrm{P}- \\
\text { value }\end{array}$ \\
\hline Maternal request & 40 & 26.5 & \multirow{9}{*}{0.000} \\
\hline Failure to progress of labor & 30 & 19.9 & \\
\hline Fetal distress & 27 & 17.9 & \\
\hline Abnormal presentation & 21 & 13.9 & \\
\hline $\begin{array}{l}\text { Hypertensive disorder of } \\
\text { pregnancy }\end{array}$ & 13 & 8.6 & \\
\hline Postdate & 10 & 6.6 & \\
\hline Antepartum hemorrhage & 6 & 4.0 & \\
\hline Multiple pregnancy & 3 & 1.9 & \\
\hline $\begin{array}{l}\text { Fetal } \\
\text { abnormality(hydrocephalus) }\end{array}$ & 1 & 0.7 & \\
\hline Total & 151 & 100.0 & - \\
\hline
\end{tabular}

${ }^{*}$ Chi-square test (Goodness of Fit) was used. 
Seventy-seven $(11.5 \%)$ of participants women delivered by CS due to maternal request. Fifteen women (19.5\%) were reported as a cause of maternal request for fear of vaginal delivery, social reasons, to obtain tubal ligation and believing of more safety to the mother and to the newborn (the number was equal by chance) and the lowest cause for maternal request for CS was avoiding delivery pain $(2.6 \%)$ with no significant statistical difference $(P=0.052)$ as appeared in table 5 .

Table 5: Distribution of the study population according to the causes of the maternal request

\begin{tabular}{|l|l|l|l|}
\hline Maternal request & No. & $\%$ & $\begin{array}{l}\text { P- } \\
\text { value }\end{array}$ \\
\hline Fear of vaginal delivery & 15 & 19.5 & \multirow{2}{*}{} \\
\cline { 1 - 3 } Social reasons & 15 & 19.5 & \multirow{2}{*}{0.052} \\
\hline To obtain tubal ligation & 15 & 19.5 & \\
\cline { 1 - 2 } $\begin{array}{l}\text { Believing of more safety } \\
\text { to the mother }\end{array}$ & 15 & 19.5 & \\
\cline { 1 - 2 } $\begin{array}{l}\text { Believing of more safety } \\
\text { to the newborn }\end{array}$ & 15 & 19.5 & \\
\cline { 1 - 3 } To avoid delivery pain & 2 & 2.6 & \\
\hline Total & 77 & 100.0 & - \\
\hline
\end{tabular}

\section{DISCUSSION}

This study gives idea about indications for CS and some characters of women which could be related to CS in Mosul city.

Our study finding showed that most age group of women delivered by CS was 20-35 years because in our locality the women with the age of $\geq 35$ preferred home deliveries especially if they had previous history of safe home deliveries. The rate of CS was low in age group of $<20$ years due to less fertility rate ${ }^{16}$. The finding was similar to a study in India ${ }^{16}$ which showed that the CS rate was also more in age group of 20-35 years as it constituted $55.6 \%$.

Due to the higher obstetrical facilities and services, high numbers of maternal health center and availability of private health care services in urban area in addition to the presence of hospitals in some rural areas where rural women go to delivered there, this study showed a higher rate of $\mathrm{CS}$ in women lived in urban region that similar to other studies ${ }^{17,18}$ in Vietnam and in the Maternity Teaching Hospital in Erbil City, Iraq.

In this study, three quarters of the women delivered by CS had education of primary school level or illiterate and this high percentage could be explained by the fact that low educational level give less importance to ante natal care (ANC) which make complications at time of deliveries more as ANC contributed to a better birth outcome 19. This study was similar to study in Kirkuk governorate ${ }^{20}$ where $70 \%$ of study sample were primary school level or illiterate.

Concerning parity, multiparous women who had 1-5 children and delivered by CS constituted three quarters of CS in this study and this high rate of $\mathrm{CS}$ in those women could be due to the preference of grand multiparous women to home deliveries and majority of primiparous women had regular ANC in primary health care centers for vaccination and examination. This percentage $(75.3 \%)$ was slightly less than percentage reported in study ${ }^{(18)}$ in Erbil City, Iraq in which CS percentage among multiparous $83.5 \%$.

Elective CS constituted the higher rate $57.5 \%$ among caesarean deliveries in this study as previous two or more CS which is unavoidable cause for CS and maternal request for elective CS are seen in high numbers in this study. It is lower than the study which was done in a tertiary care hospital at Kolkata ${ }^{21}$ in which elective CS was $81.1 \%$.

In this study, women with history of scared uterus constituted the higher rate of CS $54.8 \%$ and the rate was higher than the rate in a study done in Muhimbili National referral hospital in Tanzania ${ }^{22}$ in which repeated CS constituted $30.2 \%$.

Mascarello KC ${ }^{23}$ encouraged repeated CS for women who had previous scar but "American College of Obstetricians and Gynecologists" 24 encouraged vaginal birth after CS (VBAC) because it has been associated with fewer complications than repeated CS. There were other encouraging studies to allow trail of labor after one scar and one of these studies was done before few years in one of Mosul hospitals (Al-Batool Hospital) ${ }^{(12)}$ which showed successful rate of vaginal birth after CS in $82 \%$. So in Mosul hospitals, trial of labor after caesarean was allowed after good evaluation of women and their indications of previous scar in their work. In the current study, the rate of previous one CS with other cause was reported in $22.5 \%$ and it was lower than the rate in study done in a Bangladesh ${ }^{25}$ where the percentage was $35 \%$, this difference could be due to the level of the health care facilities. In our study the major three causes in addition to previous scar were maternal request $26.5 \%$ followed by failure to progress of labor $19.9 \%$ and fetal distress $17.9 \%$. Al-Wazzan study ${ }^{12}$ showed that no progress of labor constituted $38 \%$ followed by abnormal presentation $22 \%$ and fetal distress $9 \%$ in cases with previous CS, this difference could be related to difference in the medical approach for suspected cases of fetal distress and the increase of fear from litigation.

In our locality, all cases of previous two or more CS delivered by CS and it considered as an absolute indications for CS due to very busy hospitals in our locality in addition to the difference 
in health facilities between the centers and unavailability of continuous monitoring of intra uterine pressure and fetal heart rate monitoring for that reasons CS after two scar considered as unavoidable indications for CS and it 's rate in this study was $32.3 \%$ which was higher than the rate in study done in Iran ${ }^{27}$ which revealed that $16.1 \%$ of the women who had two or more CS. Study ${ }^{26}$ done in India which was reported no trial of vaginal delivery was given to women with previous two or more CS.

The primary CS constituted $45.2 \%$ which was nearly the rate in study done in Iran ${ }^{27} 47.1 \%$. In the current study the top three indications for primary CS $45.2 \%$ were fetal distress $25.4 \%$ followed by more than one cause for CS $19.8 \%$ and abnormal presentation $18.2 \%$. Comparing the indications of CS with other regions such as Tanzania ${ }^{28}$ showed that the three common indications for CS were obstructed labor 30\%, abnormal presentation $20 \%$ and fetal distress $11 \%$. These differences could be explained by difference in health care facilities. Fetal distress was the indication of CS in quarter of cases and this could be explained by the unavailability of continuous monitoring cardiotocography (CTG) and fetal blood sampling to check the fetal wellbeing.

Unnecessary CS due to maternal request in this study could be related in most of the women to the fear of vaginal delivery, social reasons, obtaining tubal ligation, believing of more safety to the mother and the newborn and the least cause for maternal request was to avoid delivery pain. In the current study CS on maternal request constituted $11.5 \%$ and it was higher than the rate reported in the United States ${ }^{29}$ as reported $2.5 \%$.

\section{CONCLUSIONS AND RECOMENDATIONS}

The main indications for CS in the present study were primary CS followed by previous two or more CS (unavoidable indication) and then followed by previous scar with other causes. Fetal distress was the main cause for primary CS. Maternal request was founded in some cases due to different explanation for the request. It is recommended to improve health education to the mother about the risk of CS and possibility of normal delivery after primary CS in order to decrease incidence and decrease maternal request for that.

\section{ACKNOWLEDGMENTS}

I would like to express my acknowledgments to staff members of Family and Community Medicine Department, College of Medicine, University of Mosul, Iraq.

Conflict of Interest: None.

\section{REFERENCES}

1.Byamugisha J. , Adroma M. Caesarean Section in Low, Middle and High Income Countries. In Recent Advances in Cesarean Delivery, IntechOpen (2020).

2. Osegi N, Makinde Ol. Towards optimizing caesarean section: a five-year review of caesarean sections at a Southern Nigeria hospital. International Journal of Reproduction Contraception, Obstet. Gynecol.,2020;9 (1): 205-211.

3.Zaigham M, Hellström-Westas L, Domellöf $M$ and Andersson $\mathrm{O}$. Pre labor caesarean section and neurodevelopmental outcome at 4 and 12 months of age: an observational study. BMC Pregnancy and Childbirth, 2020; 20 (1): 1-7.

4. Kenny LC and Myers JE. Obstetrics by Ten Teachers, 20 th Edition, CRC Press, Taylor and Francis Group, 2017, International Standard Book Number-13:978-1-4987-4439-3:245-250.

5. Mylonas I and Friese K. Indications for and Risks of Elective Cesarean Section. Deutsches Arzteblatt international, 2015; 112 (29-30): 489495. Doi:10.3238/arztebl.2015.0489.

6. Gohil N, Parikh R. , Koli D. To study the incidence and type of surgical difficulties encountered in repeat cesarean section in comparison with the primary cesarean sections. International Journal of Medical and Biomedical Studies,2020;4(1). https://doi.org/10.32553/ijmbs.v4i1.848.

7.Spaans WA, van der Vliet LME, Röell-Schorer EAM, Bleker OP. , van Roosmalen J. Trial of labor after two or three previous caesarean sections. European J. Obstet. Gynecol. Reprod. Biol., 2003; 110 (1): 16- 19.

8. Coutin AS. Essential obstetric and newborn care.2015 edition. Medecins. Sans Frontieres. ISBN Number: 2-906498-98-X. 130-133.

9.Kan A. Classical Cesarean Section. The Surgery Journal, 2020; 6(Suppl 2):S98.

10. Dr Kaushal. Indications for Cesarean Section: Mnemonics, 2017. https://notesmedicalstudent.blogspot.com.

11. Keedle $H$, Peters L, Schmied V, Burns E, Keedle W, Dahlen HG. Women's experiences of planning a vaginal birth after caesarean in different models of maternity care in Australia. BMC Pregnancy and Childbirth, 2020; 20 (1):115.

12. Al-Wazzan RM. Factors affecting success of trial of labor after previous one lower segment Caesarean section. Annals of the College of Medicine. Mosul, 2010; 36 (1 \& 2): 121-129.

13. İlhan G, Atmaca FFV, Eken M, Tavukçuoğlu Z, Özel A, Özdemir $M$, et al. What is Turkish women's opinion about vaginal delivery? Turk. J. 
Obstet. Gynecol., 2015; 12: 75-78. DOI:10.4274/tjod.59913.

14. Bagheri A, Alavi NM, Abbaszadeh F. Iranian obstetrician's views about the factors that influence pregnant women's choice of delivery method: A qualitative study. Women and Birth, 2013; 26 (1): 45-49.

15. Hull $P$ M. Findings do not inform maternal request caesarean risk. BMJ, Publishing Group Ltd \& Royal College of Paediatrics and Child Health; 2020. ISSN 0003-9888.

16. Verma V, Vishwakarma RK, Nath DC, Khan HTA, Prakash R, Abid O. Prevalence and determinants of caesarean section in South and South East Asian women. PLOS ONE, 2020; 15 (3): 0229906.

17. Toan TK, Eriksson B, An PN, Chuc NTK, Bongjers G, Gottvall K. Technology preference in choices of delivery care utilization from user perspective a community study in Vietnam. American Journal of Public Health Research, 2013; 1 (1): 10-17.

18. Ahmed HM. , AL-Tawil NG. Rate and indications of cesarean section in the Maternity Teaching Hospital in Erbil City, Kurdistan region, Iraq. Zanco Journal of Medical Sciences,2018 ;22 (2): 148-154. https://doi.org/10.15218/zjms.2018.020.

19. Okeke EN, Wagner Z. , Abubakar IS. Maternal Cash Transfers Led To Increases In Facility Deliveries And Improved Quality Of Delivery Care In Nigeria: Study examines the prevalence of delayed entry, the reasons for the delays and their effect on Medicaid spending in a recent cohort of brand-name medications. Health Affairs, 2020; 39 (6): 1051-1059.

20. Salih H S. Mothers Fear from Caesarean Section in Kirkuk City. kufa Journal for Nursing sciences, 2016; 6 (1): 224-229. ISSN: 22234055.

21. Chakrabarti S. Frequency and Indication of Emergency Caesarean Section in a Tertiary Care Hospital in Kolkata: Analysis of Secondary Data. Natl. Journal Community Medicine, 2018; 9 (1): 5-9.

22. Nelson JP. Indications and appropriateness of caesarean sections performed in a tertiary referral centre in Uganda: a retrospective descriptive study. The Pan African Medical Journal, 2017; 26 (62).

23. Mascarello KC, Matijasevich A, Barros AJD, Santos IS, Zandonade E. , Silveira MF. Repeat cesarean section in subsequent gestation of women from a birth cohort in Brazil, Reproductive Health, 2017;14:102.

24. American College of Obstetricians and Gynecologists. ACOG Practice bulletin no. 115: Vaginal birth after previous cesarean delivery. Obstet. Gynecol., 2010; 116(2 Pt 1): 450-463.
25. Mselenge HM, Andrea BP, Daudi OS. , Roosmalen JV. How rational are indications for emergency caesarean section in a tertiary hospital in Tanzania? Tanzania Journal of Health Research, 2012; 14(4).

26. Kose V\& Sadhvi K. Study of caesarean section at tertiary care centre: a retrospective study. International Journal of Reproduction, Contraception, Obstetrics and Gynecology, 2020; 9(5): 2139-2143.

27. Rezaie SB, Torkashvand F, Karami M, Shelkh FM, \& Manshori A. A survey on causes of cesarean sections performed at the university hospitals of Niknafs and Ali-lbn Abi Talib of Rafsanjan, Iran,. Journal of Occupational Health and Epidemiology, in the second trimester of 2014; 3 (2): 104-111.

28. Stokke SJ., Becher LMW. Indications for Cesarean Section at St. Joseph Medical Hospital, Moshi Tanzania, University of Oslo, Norway (Master's thesis), 2013.

29. Wang X, Hellerstein S, Hou L, Zou L, Ruan Y \& Zhang W. Caesarean deliveries in China. BMC pregnancy and childbirth, 2017; 17(1): 54. 